\title{
The application of cooperative learning theory in College English Multimedia Teaching
}

\author{
WANG Lei $^{1, \text { a }}$ \\ ${ }^{1}$ Jilin Business and Technology College, Changchun 130000,China \\ aemail: wanglei@126.com
}

Keywords: Cooperative learning; English learning; multimedia teaching

\begin{abstract}
According to cooperative learning is to heterogeneous study group as the basic form, the system uses the interaction between the dynamic factors of teaching, to promote students' learning, in group performance evaluation criteria together to achieve teaching objectives of teaching activities. Cooperative learning, teaching process is a teacher and students, students and students in all directions, multi level, multi angle information interaction process. Cooperative learning theory follows the law of students' cognition, interpersonal relationships within the teaching and learning reform as a breakthrough, efforts to mobilize students' active participation in the learning process actively, take the student as the center, give full play to their autonomy and initiative and improve the academic performance of students, promote students to form good non cognitive qualities remarkable effectiveness.
\end{abstract}

\section{Introduction}

At present, China's College English teaching still adopts the traditional teaching mode, students are passive learning, students' personality, ability can not be effectively. In order to deepen the cultivation aim of the undergraduate education, to infiltrate quality-oriented education to professional education, topic from the cooperative learning teaching mode of the control method, cultivating students' cognitive and non cognitive ability in the teaching of integrated skills of English, make the freshmen to adapt to university study and life.

At the beginning of 20 century 70 since the rise in the United States, it is now widely used in many countries in the world a rich creative and effective teaching theory and strategy system. There are studies have shown that cooperative learning is conducive to enhancing learners' strategy awareness; helps to eliminate the self center, promote the development of students' social adaptability. It reflects the teaching activities of the society and classes to become a true collective; communicative activities between the students, to enable students to understand the social role norms, effectively cultivate normative consciousness, sense of mission, cooperation consciousness, sense of responsibility and team spirit of cooperation. The United States, Canada and many countries from primary school to university is widely used for learning www.51lunwen.com. 20 century 80 years, cooperative learning more and more by many educational researchers concern, which in College English teaching is gradually began to promote, and achieved good results, such as Wang duqin Beijing Institute of petro - Chemical 1 in College English reading, vocabulary and writing in the teaching of using cooperative learning. Practice has proved that cooperative learning in the cultivation of students' sense of cooperation, enhance learning strategy play to the positive role; Beijing Normal University Zhu Xun 2 in college oral English teaching implementation of the concept of cooperative learning; Jinan University Zhang faker, Zhaoting 3 in College English Reading Teaching in the application of cooperative learning and achieved good results. However, the research on cooperative learning of College English Majors in higher learning institutions is rare.

First, this research is helpful to the construction of the new teaching mode of English major in University. The first year of college is a special stage of linking up middle school and university. How to make the students in the first grade of College English major courses to complete the transition from high school to cooperation and independent type is a question worth exploring. 
Second, this paper embodies the humanistic care. From school to university, ideological concept, learning method and the mode of life will have a great change, these changes make just step into the door of University Freshmen in the process from dependence to independence in had a lot of discomfort. The significance of cooperative learning is to enhance Freshmen's psychological, learning and adaptation ability, reduce neonatal adaptation cycle, enhance the students' learning motivation, reduce anxiety, strengthen confidence, promote the students' psychological health, enhance the overall quality of students. Third, this research will promote the reform of teachers colleges and universities English specialized subject. This topic research can not only make normal college English teachers to improve classroom teaching, but also to open up the second classroom has guiding significance; research of this topic not only for normal college English major teachers and middle school English teachers provide the feasibility of the method and the way, also can be used for other professional teachers for reference and reference[1].

\section{Theory of subject research}

According to cooperative learning is to heterogeneous study group as the basic form, the system uses the interaction between the dynamic factors of teaching, to promote students' learning, in group performance evaluation criteria together to achieve teaching objectives of teaching activities. 4 cooperative learning, teaching process is a teacher and students, students and students in all directions, multi level, multi angle information interaction process. Cooperative learning theory follows the law of students' cognition, interpersonal relationships within the teaching and learning reform as a breakthrough, efforts to mobilize students' active participation in the learning process actively, take the student as the center, give full play to their autonomy and initiative and improve the academic performance of students, promote students to form good non cognitive qualities remarkable effectiveness.

The application of cooperative learning to college English Majors in Comprehensive English class, create a harmonious learning atmosphere for students, cultivate students' cognitive ability (spoken, reading level; learning strategies) and non cognitive ability (personality, self-confidence, innovation, the spirit of cooperation; social ability), optimize the teaching effect.

experimental control method. In this study, the use of cooperative learning model in the experimental class, using the traditional teaching mode in the control class, after the experiment, the questionnaire was used to compare and analyze. 2 educational observation method. In the course of teaching practice, we implement two kinds of classroom observation method: participant observation and spectator observation. 3 educational survey. At the end of the experiment, two times with a questionnaire to investigate the effect of cooperative learning. Prior to this, to design a good questionnaire, and experts, professors, and then randomly selected students to pre experiment, the final release, collection, statistics. English reading, as language learning, say, read, write one of the four skills, plays an important role in English learning. For a long time, our English reading teaching has been taking the teacher as the center, taking the examination as the control, based on the vocabulary and grammar. Students as passive knowledge recipients, after years of English learning, still can not be fluent in English reading. The author's student also is so. While the focus of our new curriculum reform is to change the English curriculum too much emphasis on English grammar and vocabulary knowledge, explain and impart, emphasized that the curriculum from the student's learning interest, life experience and cognitive level of advocates experience, practice, participation, cooperation and exchange of learning and task based teaching approach. " For this purpose, the author makes a serious reflection on the teaching of English reading class, and thinks that cooperative learning is a kind of supplement and breakthrough to the traditional class teaching system. "Cooperative learning" is a student in the group work together to achieve a common goal of a learning method is to concern group learning or task based learning model, it reflects the characteristics of human communication and cooperation, can effectively cultivate students' cooperative spirit, realize English learning "participation, practice and communication." At present, cooperative learning, as a kind of advanced learning method, has been widely used in the teaching practice of students as the main body, which has become an important breakthrough and supplement 
to traditional teaching organization form. This paper focuses on how to teaching effective cooperation learning activities in junior high school English reading, mobilize the enthusiasm of students learning English, and comprehensively improve... More students the ability of language application, especially to improve their English reading achievement, and to train the student read in the English reading class solidarity and cooperation, the courage to forge ahead, good communication, good quality. This study first elaborated the advantages and disadvantages of the definition of cooperative learning, the theoretical basis and cooperative learning teaching practice and the application of cooperative learning in junior high school English reading teaching, through the experiment to verify the cooperative learning is helpful to improve the students' reading performance, to enhance students' English learning motivation for learning, active classroom atmosphere. The subjects of this study are thirty-sixth students in grade two in Hohhot City, one of the two classes[2], one is the experimental class, one is the control class. The English reading class in the experimental class adopts cooperative learning mode, while the control class still adopts the traditional reading teaching mode. In the experiment, the method of reading test, questionnaire and interview were used to collect the data. This paper is divided into five parts, on how to use cooperative learning in junior high school English reading class to do a more systematic study. The first part introduces the background of this study and points out the purpose and significance of the study. The second part: literature review. Respectively expounds the application of cooperative learning of the concepts and theoretical basis, cooperative learning in language learning in the benefits and English reading teaching and the current research status, cooperative learning applied to English reading lesson of this research provides a theoretical basis for the full. The third part: the core of this paper. The hypothesis, experimental objects, experimental tools and process of the study were determined. The experimental class and the control class a total of 121 students by test method, questionnaire survey method, interviews, from March 2007 to July 2008, for a period of nearly a year of English reading class the quantitative and qualitative experiments are carried out. In the fourth part, the results of the experiment are stated, illustrated and discussed. The benefits and problems of using cooperative learning in English Reading Course in junior middle school are analyzed. The fifth part: the conclusion of this study, summarizes the theory of cooperative learning and its application prospects. This study through the author's own teaching experimental study, in order to explore the new model of English Reading Teaching in junior high school to do some useful attempts, but also because of the teaching site, class capacity and other objective factors, there are limitations.

\section{Research strategies and methods}

Constructivism theory holds that human reason is the product of the social collective, and learning can not be based on the individual, emphasizing the importance of learning partners, and promote the learning model of group cooperative learning. This is because:

(1) the exchange, the dispute and the significance of the study are helpful for learners to construct a new and deeper understanding.

(2) in cooperative learning and learners through communication, discussion, cooperation and their ideas, to solve the problem of the ideas are clear and explicit, the learners can better monitoring of their own understanding and thinking process.

(3) in the exchange of learning to solve every problem, they have to achieve a common understanding of the problem, to construct a more complete representation of the characteristics, which is the key to solving the problem. The cooperative learning theory of constructivism and Viggo J Ki's attention to the social intercourse are consistent with the idea of "the zone of proximal development" of students[3].

The most effective means of stimulating motivation is to establish a kind of "interest community" in classroom teaching ". Group cooperative learning is the creation of such a situation, prompting each member in the group cooperative learning to try to make their own best, active learning, discusses the knowledge, to promote the overall development of the class, the class community. 
The National English curriculum standards, "to this end of cooperative learning especially emphasis" basic education curriculum reform program (Trial) "in the first part of" curriculum reform goals requires the students to collect and process information, the ability to acquire new knowledge ability, analyzes and solves the question ability, communication and cooperation ability ". The Ministry of Education promulgated the "English curriculum standard" in the autumn of 2001, which is a guiding and programmatic document for the reform of English curriculum. "English curriculum standards," pointed out that to "create a variety of cooperative learning activities, encourage students to learn from each other, help each other, to experience a sense of collective sense of honor and achievement, development of the spirit of cooperation, make the students" understanding of advantages and disadvantages of their own learning, willing to cooperate with others, foster to harmonious and healthy to the character ".

study the practical significance:

1) cooperative learning. The students' subject status is more prominent, more conducive to the cultivation of students' spirit of social cooperation and the ability of interpersonal communication is new course to achieve the students to learn the transformation of the mode of the focal point, through cooperative learning, can also train students to learn to behave, learn to do, learn to survive. Visible, how to reform the English classroom teaching mode, the creation of cooperative learning activities, and promote the students to learn from each other and help each other, to experience a sense of collective sense of honor and achievement, development of the spirit of cooperation, improve the effectiveness of language teaching, the cultivation of Talent International Exchange ability, is an urgent need to address the problem.

2). Teachers to adapt to the demands of the information age, personally to explore various aspects of education ideas, teaching methods, teaching contents, teaching methods, teaching means, teaching methods and teaching management reform, to adapt to the new era of education all-around revolution[4].

3). To optimize the teaching process, to achieve "low consumption, high efficiency and high quality" goal. Making full use of modern information technology as a cognitive tool for students to acquire new knowledge in a new way. Teachers become the whole teaching process active participants, organizers, guides, helpers, students become learning process participants, explorer and collaborators.

4) paving the way for teacher professional development. Renew teachers' educational ideas, further improve the ability of teachers to use modern educational technology, collect, process and integrate information, improve the efficiency of classroom teaching, and cultivate a large number of outstanding teachers.

5) to enhance the quality of school education, and promote sustainable development. Through the research, the school's existing scientific research results in a certain range of the model and the role of radiation, to play the leading role of the school.

1 , task definition

Cooperative learning is a kind of teaching mode, which is composed of two or more than two individuals to form cooperative learning group. Cooperative learning, also known as the common learning, its theory has a good foundation of social psychology. The core of this theory is very clear: when all men gather together for a common purpose and work, by the power of mutual unity. Rely on each other for individuals to provide the power, make them: (1) for reciprocal exemption, willing to do anything to the success of the group: (2) mutual assistance, in the team's success; (3) love each other because people like others to help themselves to achieve the purpose, but cooperation is the most can increase the contact between the members (Slavin, 1990). The subject of this research is the problem of cooperative learning in English Writing Teaching in middle school.

2 , the subject of research objectives

(1) the students' subject consciousness and independence ability is the basic quality of the development of the spindle and motivation, and cooperation consciousness and ability is students from "independent" to "social self" and "self" to "collective self" to two kind of "self" and the organic combination of necessary conditions. Only activating students' cooperative consciousness 
and ability can promote the healthy development of students' personality.

(2) to enrich the knowledge of English, improve the level of English, enhance the ability to use English is the need of the development of the times, but also affect the students' awareness of cooperation and the ability to develop one of the key factors. The implementation of independent variables in the classroom operation, not only conducive to the cultivation of students' awareness and ability, but also through effective cooperative learning to promote the harmonious development of the overall quality of students[5].

3 , the training objectives

The core of the development of individual overall quality is the harmonious development of individual and society.

\section{Conclusion}

Learn to know, learn to work, learn to live together, learn to survive is the four pillars of the development of modern life. One of the major issues in education today is to learn to live together. One mission of education is to educate the students to understand the diversity of human beings, and to have the similarity and interdependence among all people, to achieve the common goal. "Cooperative learning" is an important way to train students' ability to live together with other people.

\section{References}

[1] Gu. Internet English - World roaming Peja Internet assisted English teaching [M]. Shanghai: Shanghai foreign language education press, 1998.

[2] Deng Xinghui. [J]. foreign language teaching and foreign language teaching based on multi media perspective, 2003 (9).

[3] Zhang Xiaoying, Li Tianxian. Constructivism and Multimedia Computer Assisted College English teaching [J]. foreign language teaching, 2003 (2).

[4] he Kekang. Construction of the theoretical basis for the doctrine of information technology teaching reform in higher education [Z].1997 in Hong Kong "education skills and Technology Conference" special report.

[5] Chen Li, Chen Li, Chen Meiling. Network based classroom teaching and instructional design [J]. China audio visual education, 2002 (4). 